Article

\title{
A Bridge between Society and Universities: A Documentary Analysis of Science Shops
}

\author{
Daniela De Filippo *(D), Nuria Bautista-Puig, Elba Mauleón and Elías Sanz-Casado \\ Research Institute for Higher Education and Science (INAECU), University Carlos III of Madrid, \\ 28903 Madrid, Spain; nbautist@bib.uc3m.es (N.B.-P.); mmauleon@bib.uc3m.es (E.M.); elias@bib.uc3m.es (E.S.-C.) \\ * Correspondence: dfilippo@bib.uc3m.es; Tel.: +34-916-248-468
}

Received: 30 June 2018; Accepted: 30 July 2018; Published: 1 August 2018

\begin{abstract}
Citizen science surfaced as a new way of conducting research and science shops are one of the initiatives in which citizen collaboration with scientists has been most visible. These organisations provide independent and participatory support for research in response to civil society's problems/needs. Although science shops have pioneered the furthering of citizen participation, the general public is still scantly aware of their existence. This study aimed to explore that matter, identifying and analysing the literature on science shops with bibliometric techniques. Different sources of information have been consulted; namely, Web of Science and SCOPUS database; Google Scholar; CORDIS European Projects Database; and My News. The information collected from 158 documents was analysed and their main characteristics identified. A map of science shops was constructed to show existing initiatives and those mentioned in the texts. We also offer a chronology of the main milestones on the subject mentioned in the texts. The results show the importance that countries like those in Europe, especially The Netherlands, attach to these activities and it is evident that the content can be very varied, although the environmental issues are highlighted.
\end{abstract}

Keywords: science shops; citizen science; bibliometric analysis

\section{Introduction}

\subsection{Citizen Science, Backdrop for Science Shops}

References to new scientific and technological knowledge are associated ever more closely with terms such as transparency, collaboration, and participation. That reveals a substantial change in how science is conducted today, in which the lead part is not played by scientists alone. Rather, the stage is being filled with a number of social actors who participate in all phases of research, from prelude to finale. The Open Science movement weighed heavily in this new approach to science, furthering developments such as Open Access (to scientific publications, repositories, and databases), Open Data (freely available data), participatory research (to share infrastructure and facilities), Open Innovation (corporate participation with organisations and other agents in innovative procedures), and citizen science (non-scientists who collaborate in scientific and technological projects) [1].

Citizen science surfaced as a new way of conducting research. The conceit is defined as public engagement in scientific research activities with citizens actively contributing to science with their intellectual effort, surrounding knowledge, or tools and resources. The main aim is to co-create a scientific culture and an exchange of understanding [2]. One of the features that differentiates citizen science from the traditional variety is that it is open to all citizens, not only the most 'privileged' [3]. Citizens participate throughout the process, from inception and choice of the lines of research to the performance of the tasks that might be deemed 'typical' of researchers. The scientific literature has 
defined several levels of citizen participation, such as Arnstein's 'ladder of citizen participation' $[4,5]$. Such collaboration includes not only communication-related activities, but citizens' direct participation in the scientific endeavour [6].

The origin of the term can be traced back to Alan Irwin who, in the mid-nineteen-nineties, defined a 'form of science developed and enacted by citizens themselves' [7]. Years later, in 2009, Bonney envisaged public participation, engagement, and science communication projects [8]. Today the term has a dual focus: one closer to natural and the other to social science [9]. In the former, citizen participation consists of recording observations and classifying and collecting data that are subsequently used by researchers in their projects. In the latter, they adopt a more active role, participating in decision making, for such projects that stem from their own needs and concerns.

The international organisations that foster and fund citizen science activities have identified the primary advantages of this approach. It furthers scientific literacy and critical faculties among the public at large, renders science more democratic, motivates young people to pursue scientific careers, generates new knowledge and encourages new forms of research, and expands researchers' skills [10]. It is based on the conventional research model, but differs by who collects data or how knowledge is exchanged. Many citizen science projects, particularly those done by non-governmental organizations (NGOs), do not explicitly test scientific theory, but rather focus on 'surveillance' monitoring [11]. The difficulties most often cited in citizen science activities include funding, assessment, and the sustainability of this initiatives. The researchers involved also mention the lack of personal and institutional acknowledgement inherent in this type of research [12], which induces discouragement and discontinuity. Citizens' lack of motivation and engagement in the process are likewise criticised, while the literature defines as problematic scientists' tendency to view laypersons as mere data furnishers or information compilers. Perhaps the best known participatory research project is the CERN's Large Hadron Collider, although other inspiring examples have been implemented, such as Foldit ${ }^{1}$, in which several social actors became involved. Other initiatives are geared to solving local problems, calling on the respective communities to collect data on rainfall, severe pollution, or animal migration, for instance. Although much of the citizen science movement has been associated with initiatives undertaken in less economically and technologically advantaged societies, more developed countries are no strangers to such participation. This new approach is attracting increasingly wider political, institutional, and public attention. The European Union's framework programmes constitute an example, under which funding has been provided for a number of citizen projects, including Foster+, with 13 partner institutions in eight countries, and the Eighth Framework Programme's Socientize and Citi-sense schemes. The latest H2020 Programme included several calls focusing on these issues, of which the work programme 'Science with and for Society' is an emblematic example. The growing number of conferences and events across Europe is another. Open and citizen science initiatives in disciplines as diverse as health [13], the environment [14,15], astronomy [16], or the social sciences [17] have shown the benefits of a practice in which science extends beyond open access, reaching out to social actors and feeding back into the production of new knowledge.

\subsection{Science Shops}

Science shops are one of the initiatives in which citizen collaboration with scientists has been most visible. These organisations provide independent and participatory support for research in response to civil society's problems/needs. First instituted in The Netherlands in the seventies on an initiative of a group of students seeking to solve problems in their own community, these centres have been instrumental in steering research onto a new pathway.

1 The Foldit Project, implemented at the University of Washington in 2008, sought a fuller understanding of the structure of synthetic proteins based on the experience of players participating in a cost-free on-line videogame. 
They were also associated with the nineteen-sixties social movements that called for more open and effective contact between academia and society. The first science shop, founded in the Utrecht University's Faculty of Chemistry in 1973, was followed in 1978 by another that opened at the University of Amsterdam [18]. In the nineteen-eighties, a so-called 'second wave' of institutions began to mushroom in Belgium, Denmark, France, and Germany, although their roll-out was not very tightly coordinated [19]. A third wave in the nineteen-nineties reached as far as Austria and United Kingdom, and in a fourth between 1995 and 2000, shops were set up in Central and Eastern European countries. Today, interest in their institution has spread as far as Asia, to countries such as China and Japan. In the two-thousands, the European Union also expressed an interest in such initiatives, seen as a way to link science and society. The ISSNET, INTERACTS, SCIPAS, and PERARES projects were funded in those years, which also witnessed the advent of the Europe-wide Living Knowledge (The International Science Shop) Network and its association with the Community-based Research Network in the United States and Canada. Nonetheless, a survey conducted by the SciShops Project showed that the awareness of science shops among actors such as researchers, policy makers, and organisations is relatively low [20].

The idea underlying such movements is that rather than scientists and their interests, the starting point is society itself as it endeavours to meet its needs and demands through research. The essential change is that communities such as researchers, local organisations, politicians, and others form part of the various stages of research and all participate actively in the process and the pursuit of solutions. Moreover, the findings of all the activities undertaken in this context are openly shared with society as a whole and made available to all for future use.

One of the particularities of this type of initiatives is that no single model has been established. Science shop structures and areas of interest consequently vary from country to country and shop to shop. They may have research institutes, or more commonly universities, as parent organisations, although many are the fruit of community or independent organisational action. Their existence is also in keeping with the 'third mission' entrusted to universities. The questions that give rise to scientific developments may vary, as may the expertise available in each shop; whereas in the United States, they focus more on health issues [13], and in Central and Eastern Europe, they tend to address environmental matters as well as Scandinavia social problems [11]. Another factor that affects the type of issues dealt with by science shops is the degree of citizen development and participation in scientific activities. Some studies have shown that in countries where science-society communication is 'weaker' (such as Central and Eastern Europe), few research questions are raised. In those cases, science shops develop differently than in Western Europe.

Although science shops have pioneered the furtherance of citizen participation, the general public is still scantly aware of their existence. This study aimed to explore that matter.

Its objectives were to identify and analyse the literature on science shops with bibliometric techniques. Bibliometrics, which studies academic publications, has developed useful tools for analysing scientific activity in a given subject area, institution, or country. It assesses the impact and visibility of scientific fields, journals, and researchers and has proven to be very effective in detecting new lines of research [21].

This study was consequently designed to do the following:

- Locate documents disseminating information on science shops and analyse the fluctuation in output over time;

- Identify the countries where these initiatives have proliferated most;

- Analyse the content of these publications to ascertain the particulars addressed. The documentary analysis also intended to yield two specific results to establish an overview of the origin and development of science shops.

1. The first was to map science shops. That entailed identifying the science shops in place and determining the ones cited in the analysed documents. The idea was to gain insight 
into which initiatives have gained visibility in the academic world and which have not. Findings in this respect are significant for, as science shops often engage in university knowledge transfer, their scope, limitations, and impact have not generally been analysed from a conceptual or methodological perspective.

2. The second was to create a timeline of science shop dynamics, using the documentary analysis as a tool to record and observe science shop activity over time.

\section{Materials and Methods}

As science shops are seldom a target of scientific analysis, a variety of information sources was used to compile the most extensive and varied amount of documents possible on the subject. The main sources analysed are listed below.

- Web of Science (WoS): this international, multi-disciplinary database indexes mainstream science publications, providing information from which to determine the papers of highest academic prestige in each field. It lists over 12,000 journals.

- SCOPUS: like WoS, it is one of the primary sources for analysing quality scientific output. Less restrictive than WoS, it indexes double the number of social science and humanities journals, as well as periodicals not published in core countries.

- Google Scholar: this open source search engine lists academic documents of different types, including whole books, chapters, scientific papers, and working documents. It has a far wider reach than the preceding two and is much more visible, although the quality of the documents listed does not always meet the same standards as in WoS and SCOPUS.

- CORDIS: this is a database containing information on the calls announced by European framework programmes and detailed data on science shop-related projects.

- MyNews: this is a resource providing access to media information on the international, national, and regional scales with broad subject area coverage.

In addition to the sources mentioned, the Living Knowledge Network and the International science shop network websites were visited to gather contextual information on the creation and history of all the initiatives in place. Additionally, information of the deliverables from the SciShops.eu project was consulted.

Specific downloading strategies adapted to each source were followed to retrieve information on science shops.

In WoS and SCOPUS, the topic search focused on variations on the term 'science shop' in the title, abstract, and keywords. Papers bearing the words in those three sections were retrieved.

Publications were retrieved from Google Scholar with Harzing's 'publish or perish' tool, which identified documents containing the term 'science shop' in the title. Searches were not conducted in other document fields because the results comprised an unwieldy number containing incorrect information.

The term was searched anywhere in the text in project databases and media portals.

None of the searches were filtered by dates to ensure the results would include all the documents published.

After the documents were retrieved, scientific activity indicators for particulars such as content and yearly fluctuations in output were obtained. A model template was designed to systematically gather document particulars, such as source, date, content summary, publication objectives, and actors involved in the publication.

\section{Results}

The number of documents retrieved as described in the methodology varied with the source. Table 1 lists the number gathered from each. Inter-source overlapping was observed because some 
documents were indexed in more than one database. Out of the total 158 documents identified, 67 were found in Google Scholar.

Table 1. Number of documents retrieved, by source. GS—Google Scholar; WoS-Web of Science.

\begin{tabular}{cccc}
\hline Source & 1st doc. Date & No. docs & Search Strategy \\
\hline WoS & 1979 & 38 & Title, abstract, keywords \\
SCOPUS & 1979 & 39 & Title, abstract, keywords \\
WoS + SCOPUS & 1979 & 57 & Title, abstract, keywords \\
Google Scholar & 1982 & 67 & Title only (Title, abstract, \\
GS + SCOPUS + WOS & $\mathbf{1 9 7 9}$ & $\mathbf{1 1 4}$ & keywords yielded $>1000)$ \\
My News & 2002 & 34 & Content and title \\
Projects & 2000 & 10 & Content and title \\
Total documents & & $\mathbf{1 5 8}$ & \\
\hline
\end{tabular}

The results are discussed below in two sub-sections: the first on the findings common to all the sources, that is, output over time, participating countries, and content; and the second on the data specific to each.

\subsection{Findings Common to All Sources}

A time-wise analysis of the documents on science shops showed that the first was published in 1979. Listed in the Web of Science and SCOPUS and carried in Nature, it bore the title 'Holland's science shops for made-to-measure research'. The text contained a first-time reference to Dutch scientists' efforts (deemed by the author to be 'scantly orthodox') to adapt science to social needs. Although this pioneering article (at least in mainstream science) dates from nearly 40 years ago, the review showed that most papers on the subject have been published in the last 10 years.

Output on science shops in all manners of documents was observed to follow a fairly steady, upward pattern, whereas news items and project listings in databases were much more recent, most dating from 2000 onward (Figure 1).

Documents on the subject were published by authors or institutions located in a total of 32 countries (Table 2). The type of source had an impact on distribution by country: in CORDIS, for instance, which focuses on European research, activity in other regions was obviously under-represented. Similarly, the number of items in MyNews was strongly biased toward Spanish output. Despite those limitations, The Netherlands could be readily identified as the country with the most intense activity, followed by Germany and the United States (Figure 2). Holland also headed the list of projects, which included the two aforementioned countries as well as the United Kingdom.

By type of institution, universities, particularly in The Netherlands, accounted for the largest number of documents and the most intense participation and leadership in European projects.

The type of texts most frequently found included case studies, methodological proposals (approach to participation), science shop impact, and historical and contextual analyses of these initiatives. Content characteristics could be grouped by type of document analysed (Figure 3). 


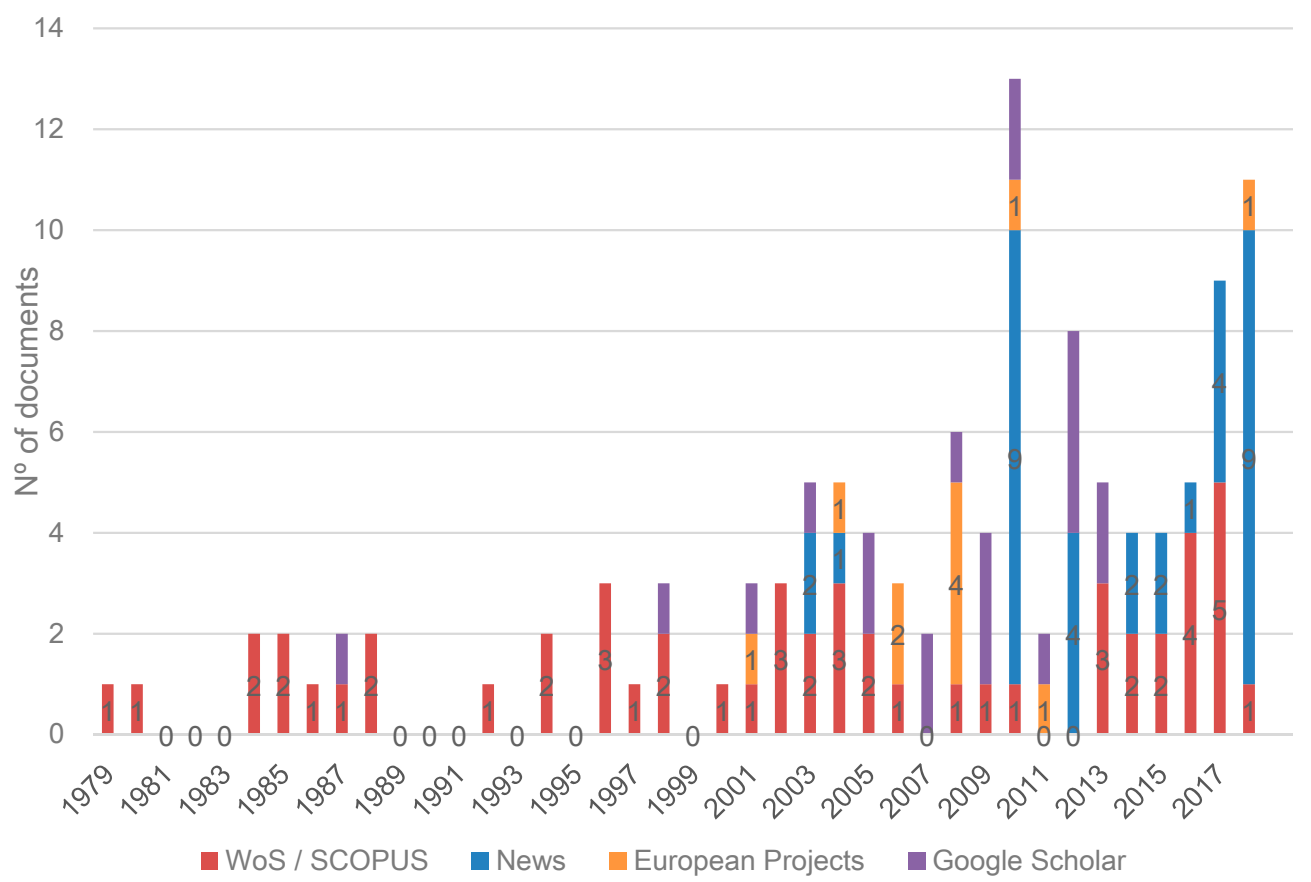

Figure 1. Number of listed publications, projects, and news items on science shops, 1979-2017. WoS-Web of Science.

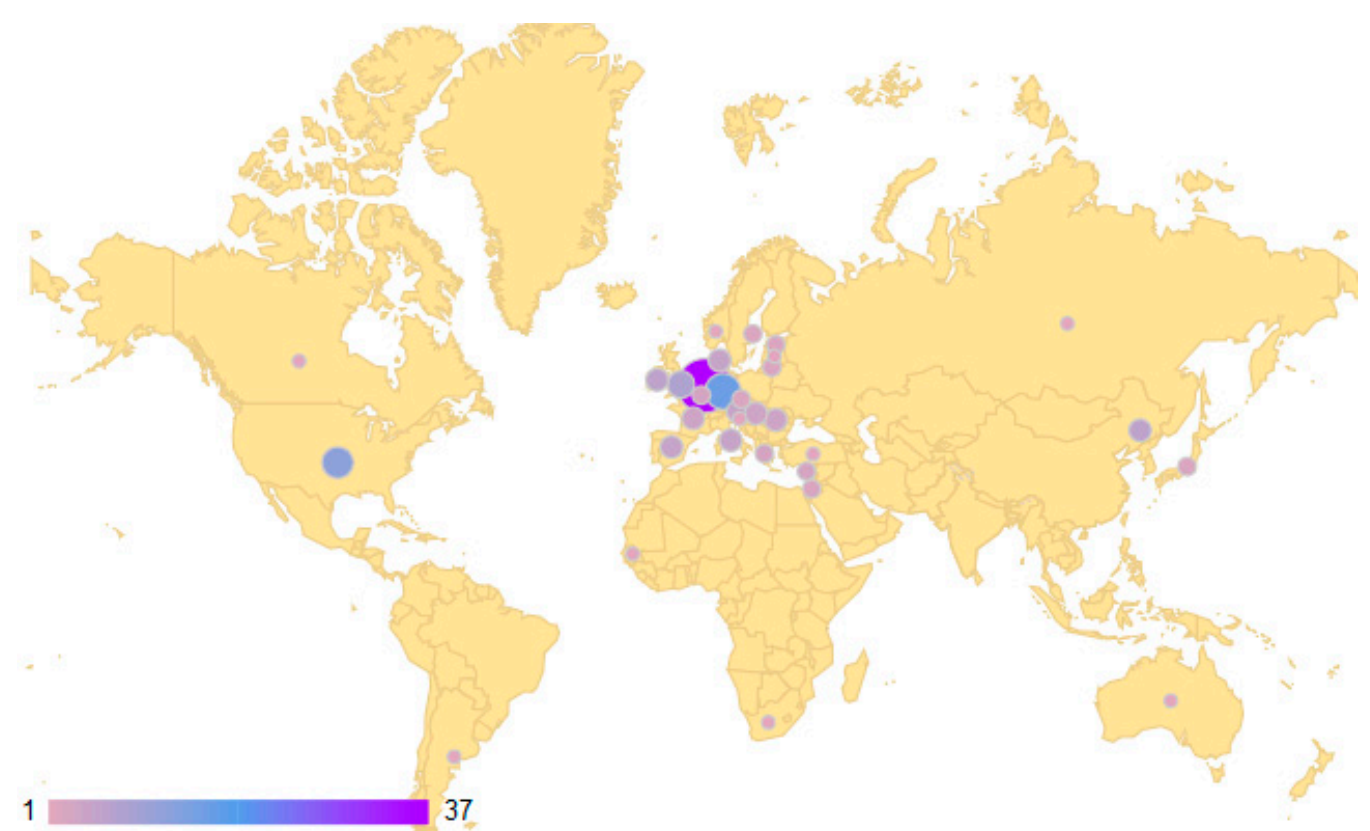

Figure 2. Worldwide distribution of publications, projects and news items on science shops. The size of the circles and intensity of the colour are proportional to the intensity of document output on science shops. 
Table 2. Document output by country in the sources analysed.

\begin{tabular}{|c|c|c|c|c|c|c|}
\hline COUNTRY & WOS & SCOPUS & $\begin{array}{l}\text { Google } \\
\text { Scholar }\end{array}$ & $\begin{array}{l}\text { Projects } \\
\text { Headed }\end{array}$ & $\begin{array}{c}\text { Project } \\
\text { Participation }\end{array}$ & NEWS \\
\hline Netherlands & 8 & 12 & 5 & 6 & 6 & 0 \\
\hline USA & 5 & 5 & 0 & 0 & 2 & 0 \\
\hline France & 2 & 1 & 0 & 0 & 1 & 0 \\
\hline Ireland & 3 & 0 & 0 & & 2 & 0 \\
\hline Australia & 1 & 0 & 0 & 0 & 0 & 0 \\
\hline Denmark & 1 & 0 & 3 & 0 & 2 & 0 \\
\hline England & 1 & 1 & 0 & 0 & 7 & 0 \\
\hline Hungary & 1 & 1 & 0 & 0 & 2 & 0 \\
\hline Italy & 1 & 2 & 0 & 0 & 3 & 1 \\
\hline Japan & 1 & 1 & 0 & 0 & 0 & 0 \\
\hline China & 1 & 0 & 5 & 0 & 0 & 0 \\
\hline Sweden & 1 & 0 & 0 & 0 & 1 & 0 \\
\hline Germany & 2 & 4 & 3 & 1 & 6 & 1 \\
\hline Romania & 0 & 1 & 0 & 0 & 3 & 0 \\
\hline Russia & 0 & 1 & 0 & 0 & 0 & 0 \\
\hline Senegal & 0 & 1 & 0 & 0 & 0 & 0 \\
\hline Spain & 0 & 0 & 2 & 0 & 3 & 28 \\
\hline Czech republic & 0 & 0 & 1 & 0 & 1 & 0 \\
\hline Argentina & 0 & 0 & 1 & 0 & 0 & 0 \\
\hline Canada & 0 & 0 & 1 & 0 & 0 & 0 \\
\hline Austria & 0 & 0 & 0 & 2 & 3 & 0 \\
\hline Greece & 0 & 0 & 0 & 1 & 2 & 0 \\
\hline Cyprus & 0 & 0 & 0 & 0 & 3 & 0 \\
\hline Belgium & 0 & 0 & 0 & 0 & 3 & 0 \\
\hline South africa & 0 & 0 & 0 & 0 & 1 & 0 \\
\hline Lithuania & 0 & 0 & 0 & 0 & 2 & 0 \\
\hline Turkey & 0 & 0 & 0 & 0 & 1 & 0 \\
\hline Israel & 0 & 0 & 0 & 0 & 2 & 0 \\
\hline Latvia & 0 & 0 & 0 & 0 & 1 & 0 \\
\hline Estonia & 0 & 0 & 0 & 0 & 2 & 0 \\
\hline Norway & 0 & 0 & 0 & 0 & 1 & 0 \\
\hline Slovenia & 0 & 0 & 0 & 0 & 1 & 0 \\
\hline
\end{tabular}

\section{Scientific papers:}

-Social and academic impact of science shops (SS)

-SS history and development

-Methodological scope and limitations

-Case studies

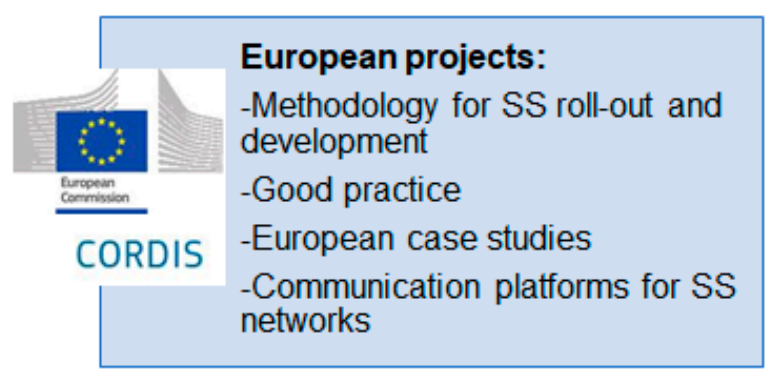

Articles, books, dissertations, congress communications:

-Case studies

-Dissemination of SS activities

-Scientific literacy

-Advantages and drawbacks to SS

\section{News items:}

-Dissemination of local SS

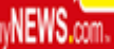
activities

-Community impact of SS development and activities -Interviews with SS and citizen science experts

Figure 3. Content in articles, books, projects, and news items on science shops. 


\subsection{Results Specific to Each Source}

The findings not accommodating inter-source comparison are discussed below.

\subsubsection{Publications Listed in WoS, SCOPUS, and Google Scholar}

A total of 43 journals carried papers on science shops. Although articles on the subject appeared only sporadically in many, $10 \%$ appeared in such a highly reputed journal as Science. The journals that carried more than one paper on the subject are listed in Table 3. Although some of the same papers were found in all three sources, each journal is shown only once in the table.

Table 3. WoS- and SCOPUS-listed journals carrying articles on science shops.

\begin{tabular}{ccc}
\hline Journal & No. docs & $\%$ \\
\hline Science & 6 & 10.53 \\
Science and Public Policy & 4 & 7.02 \\
Pharmaceutisch Weekblad & 3 & 5.26 \\
Environmental Engineering and Management Journal & 2 & 3.51 \\
Recherche & 2 & 3.51 \\
\hline
\end{tabular}

The WoS-indexed journals carrying papers on science shops were most frequently classified under the category 'Multidisciplinary Sciences', whereas those in SCOPUS with the highest output were found under 'Social Sciences', 'Humanities and Arts', and 'Environmental Science' (Figure 4).
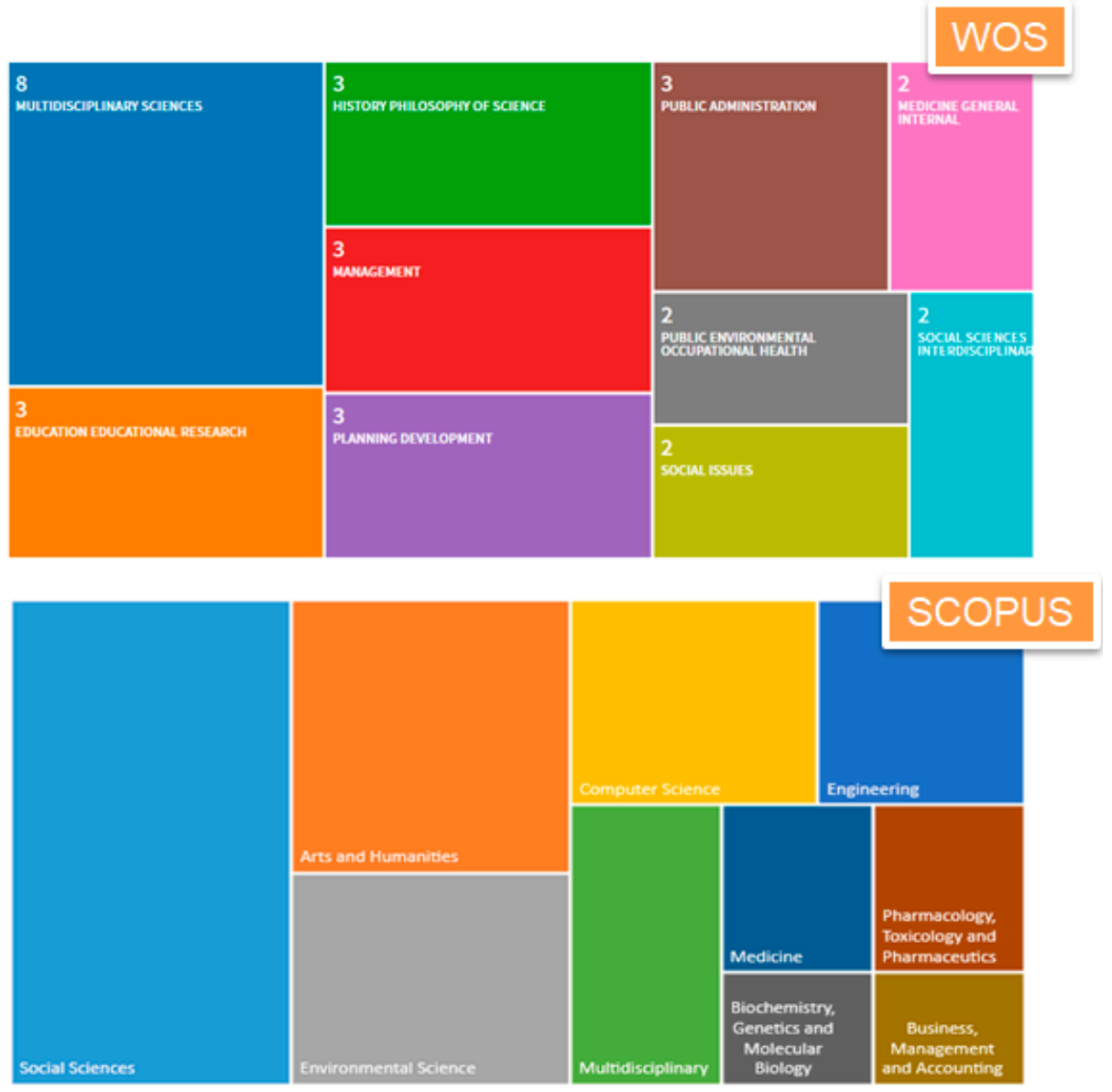

Figure 4. Journals carrying articles on science shops: WoS and SCOPUS category listings. 


\subsubsection{EU Framework Programmes}

Ten European Union Framework programmes included projects dealing with science shops. The first, SCIPAS, was awarded in 2000 under the FP5. While the number of participating institutions varied, Dutch organisations were often present both as partners and project leaders. To date, the most generous grant, for nearly three million euros, was awarded to a SciShops.eu project entitled 'Expanding the European science shop ecosystem' (Table 4).

Table 4. Characteristics of European science shop projects.

\begin{tabular}{|c|c|c|c|c|c|}
\hline Acronym & Programme & Duration & Coordinator & No. Partners & Funding $(€)$ \\
\hline COMSCIENCE & $\begin{array}{l}\text { 7FP (Science } \\
\text { and Society) }\end{array}$ & 2009-2012 & $\begin{array}{l}\text { LUDWIG MAXIMILIAN } \\
\text { UNIVERSITY OF } \\
\text { MUNICH }\end{array}$ & 8 & 794,720 \\
\hline SciShops.eu & $\begin{array}{c}\text { H2020-SwafS } \\
2016-1\end{array}$ & $2017-2020$ & SYNYO GmbH (Austria) & 18 & $2,935,887$ \\
\hline PERARES & $\begin{array}{l}\text { 7FP (Science } \\
\text { and Society) }\end{array}$ & 2010-2014 & $\begin{array}{l}\text { UNIVERSITY OF } \\
\text { GRONINGEN (The } \\
\text { Netherlands) }\end{array}$ & 28 & $2,728,041$ \\
\hline TRAMS & FP6-Society & $2005-2008$ & UTRECHT UNIVERSITY & 11 & 449,250 \\
\hline VECTOR & FP6-Society & 2007-2009 & $\begin{array}{l}\text { IVAM RESEARCH AND } \\
\text { CONSULTANCY ON } \\
\text { SUSTAINABILITY (The } \\
\text { Netherlands) }\end{array}$ & 6 & 314,483 \\
\hline PARCEL & FP6-Society & 2005-2007 & $\begin{array}{l}\text { SCIENCE SHOP VIENNA } \\
\text { (Austria) }\end{array}$ & 4 & 175,983 \\
\hline WINDFARMPERCEPTION & FP6-Society & $2007-2008$ & $\begin{array}{l}\text { UNIVERSITY OF } \\
\text { GRONINGEN (The } \\
\text { Netherlands) }\end{array}$ & 3 & 170,900 \\
\hline NEWCOM & FP6-Society & $2007-2008$ & $\begin{array}{c}\text { DUBLIN CITY } \\
\text { UNIVERSITY (Ireland) }\end{array}$ & 3 & 66,000 \\
\hline INMOSION & FP6-Society & 2007-2009 & $\begin{array}{l}\text { UNIVERSITY OF } \\
\text { THESSALY (Greece) }\end{array}$ & 7 & 395,000 \\
\hline SCIPAS & $\begin{array}{l}\text { FP5-HUMAN } \\
\text { POTENTIAL }\end{array}$ & $2000-2001$ & $\begin{array}{l}\text { UTRECHT UNIVERSITY } \\
\text { (The Netherlands) }\end{array}$ & 7 & 212,630 \\
\hline ISSNET & $\begin{array}{l}\text { FP5-HUMAN } \\
\text { POTENTIAL }\end{array}$ & 2003-2005 & $\begin{array}{l}\text { UTRECHT UNIVERSITY } \\
\text { (The Netherlands) }\end{array}$ & 12 & 396,220 \\
\hline
\end{tabular}

Network creation, one of the features characterising these projects, attests to the cooperation existing among institutions of different origins. The intense engagement on the part of Dutch and German institutions is visible in the list of participating countries shown in Figure 5. Although this is a primarily European activity, third country partners from the United States, Israel, and South Africa also participated.

\subsubsection{Items in MyNews}

Of the 34 news items identified in MyNews, 30 were related to science shops however four were discarded because there were not linked to this topic. Although this source was initially promising, substantial limitations were detected, in particular in connection with regional coverage. As Figure 6 shows, the vast majority of the items retrieved were drawn from Spanish newspapers. The items on science shops normally appeared in regional or local papers and primarily in their society and current affairs sections. 


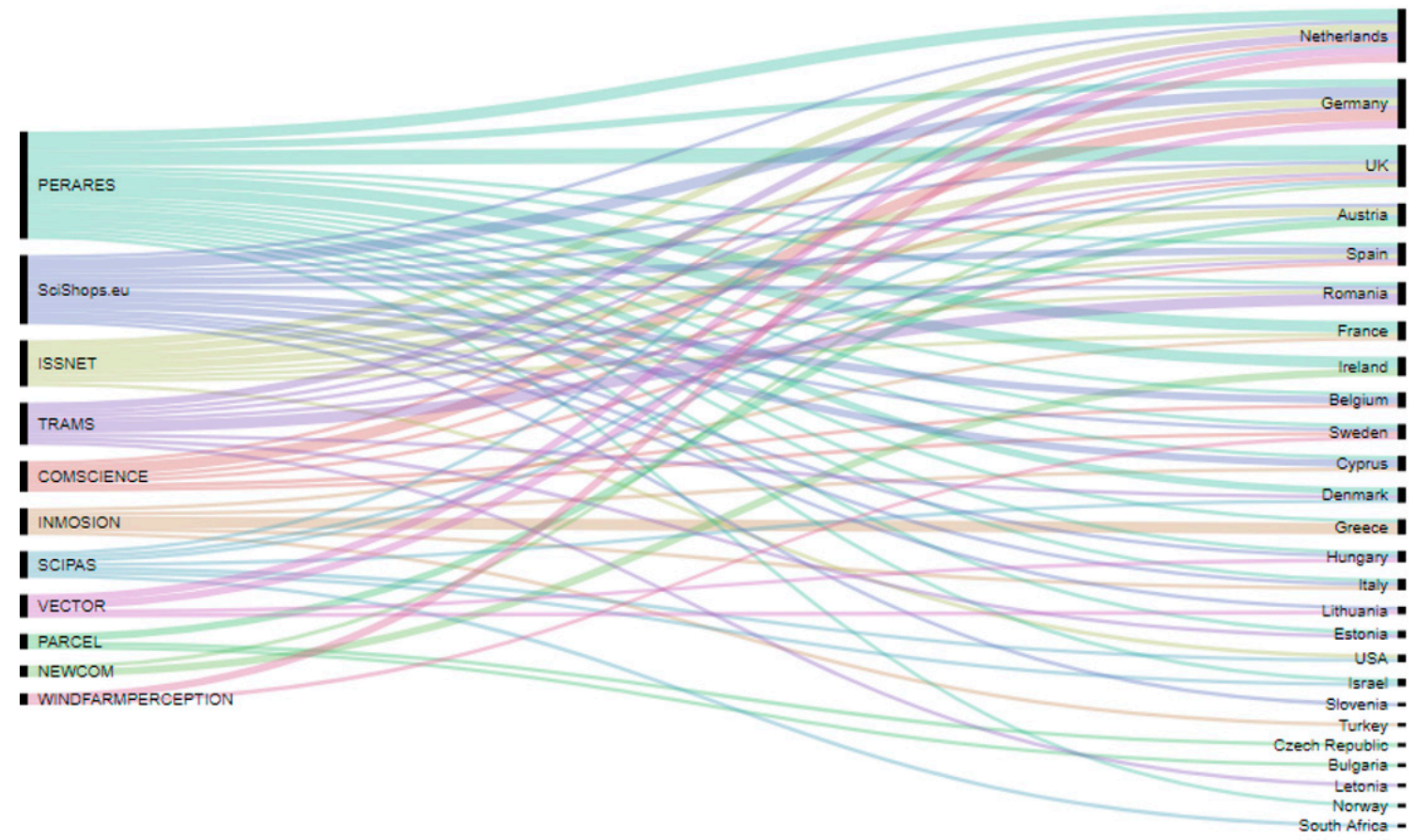

Figure 5. Cooperation among countries participating in science shop projects.

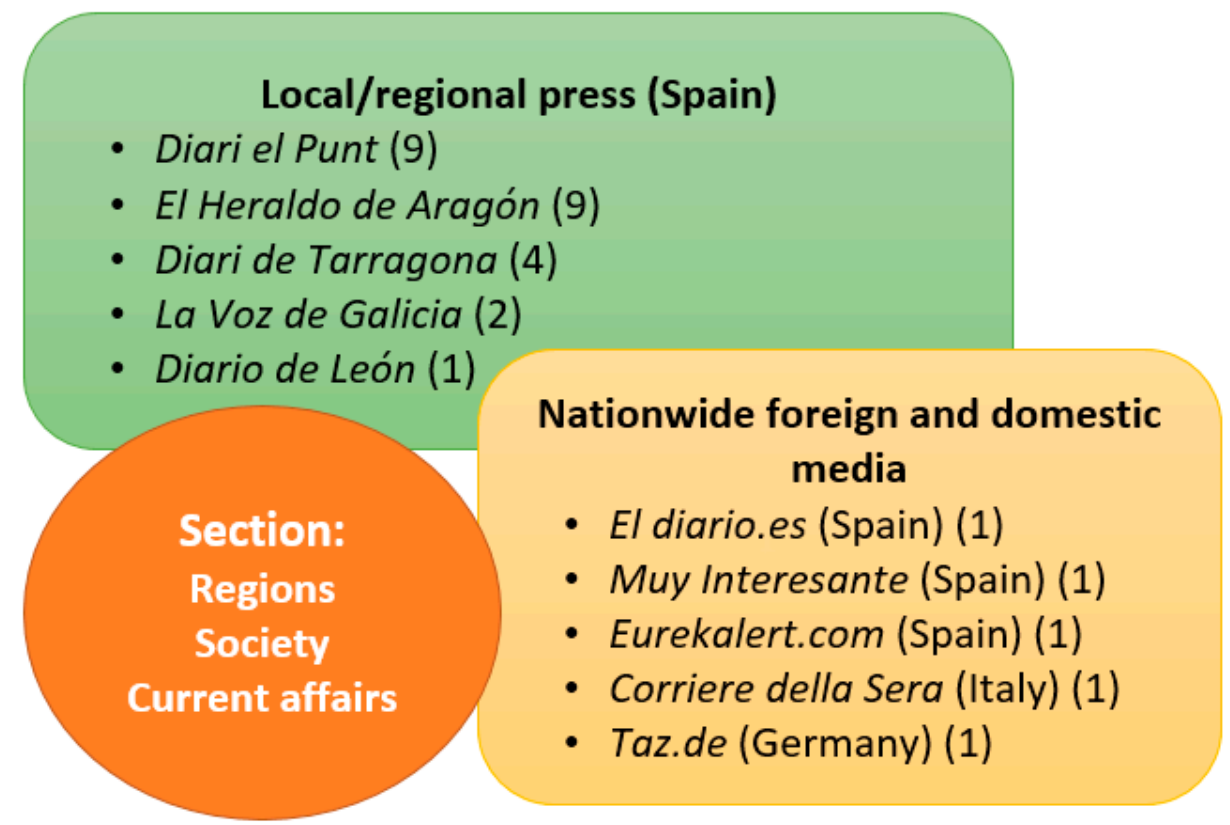

Figure 6. Characteristics of news items on science shops.

Health (especially epidemic control and primary care) and the environment (primarily waste recovery, pollution, and the carbon footprint) were the most prominent subjects dealt with by the science shops detected.

\subsection{Contributions to the Study of Science Shops}

Source analysis yielded information from which the characteristics of science shops could be defined and studied. The map of the science shops (Figure 7) shows the 152 science shops obtained through the Living Knowledge Network database and the Science Shops Taxonomy 
deliverable from the SciShops.eu project [22,23]. In the texts analyzed in this study, some other science shops were detected and were included on the list. The Science Shops mentioned on the texts were at University of Camberra (Australia); Science Shops in Pacoima (USA); International Society of Exposure Analysis (USA); Wissenschaftsladen Graz (Austria); Institut für gesellschaftswissenschaftliche Forschung, Bildung und Information (Austria); Science Shop at the University of Salzburg (Austria); Science Shop at Vienna (Austria); Patenschaftsmodell INNsbruck (Austria); Science Shop at Technological University (Denmark); Bonn Science Shop (Germany); Wissenschaftsladen kubus-Kooperations-und Beratungsstelle für Umweltfragen (Germany); Potsdam—Wissenschaftsladen (Germany); Vechta Science Shop (Germany); Clopenburg Science Shop (Germany); Science Shop at Technological University of Berlin (Germany); Science Shops at the University of Roma la Sapienza and University of Pescara (Italy); InterMediu Iasi Gh. Asachi Technical University (Romania); InterMediu Iasi Al. Ion Cuza University (Romania); Living Lab for Health-Institute for AIDS Research IrsiCaixa (Spain); Pax Mediterranea Science Shop at University of Sevilla (Spain); University of Leon (Spain); Universitat Rovira i Virgili (Spain); Architecture and Social Commitment (Spain); shop ISTAS (Spain); Liverpool—Interchange c/o Department of Sociology, Social Policy \& Social Work Studies (UK); University of Wolverhampton (UK); Universiteit van Amsterdam (Netherlands); Science Shop at Wageningen (Netherlands); Science Shops at Universities of Wushu, Shanghai and Beijin (China); Science Shop "Xam-Xamu Niep Ngir Niep" (Senegal); and the Science Shop at the University of Moron (Argentina). Considering science shops mentioned in the texts, $41(26.97 \%)$ were explicitly referenced as "case of study". It should be noted that the new science shops that are going to be created into the INSPIRES and SciShops project are not included yet on the map. Besides, the ones located in Africa are created as result of the SOHA project. The map shows that they are headquartered primarily in Europe and North America and the ones more mentioned are countries such as Germany, United States, Romania, and The Netherlands.

The documents on science shops also provided the data needed to build a timeline of their activity, as shown in Figure 8. The earliest initiatives appeared in the late nineteen eighties when Dutch scientists began to change their working perspective. Reference to such initiatives, particularly in European universities, was found in documents published over the last 40 years. Documentary evidence dating from the last 10 years was located in science shops in Asia, Latin America, and Africa. 


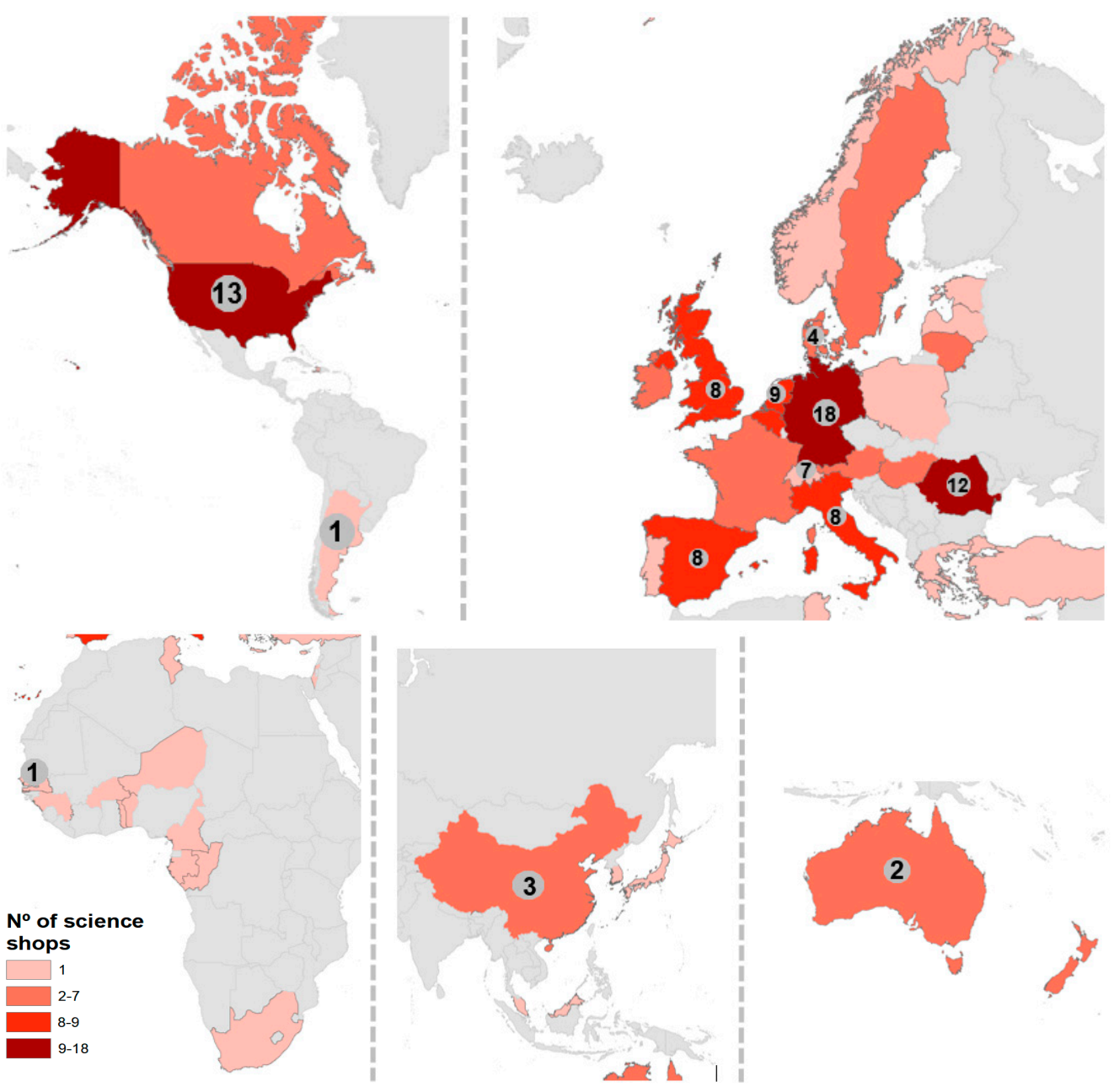

Figure 7. Map of science shops identified and their number of mentions.
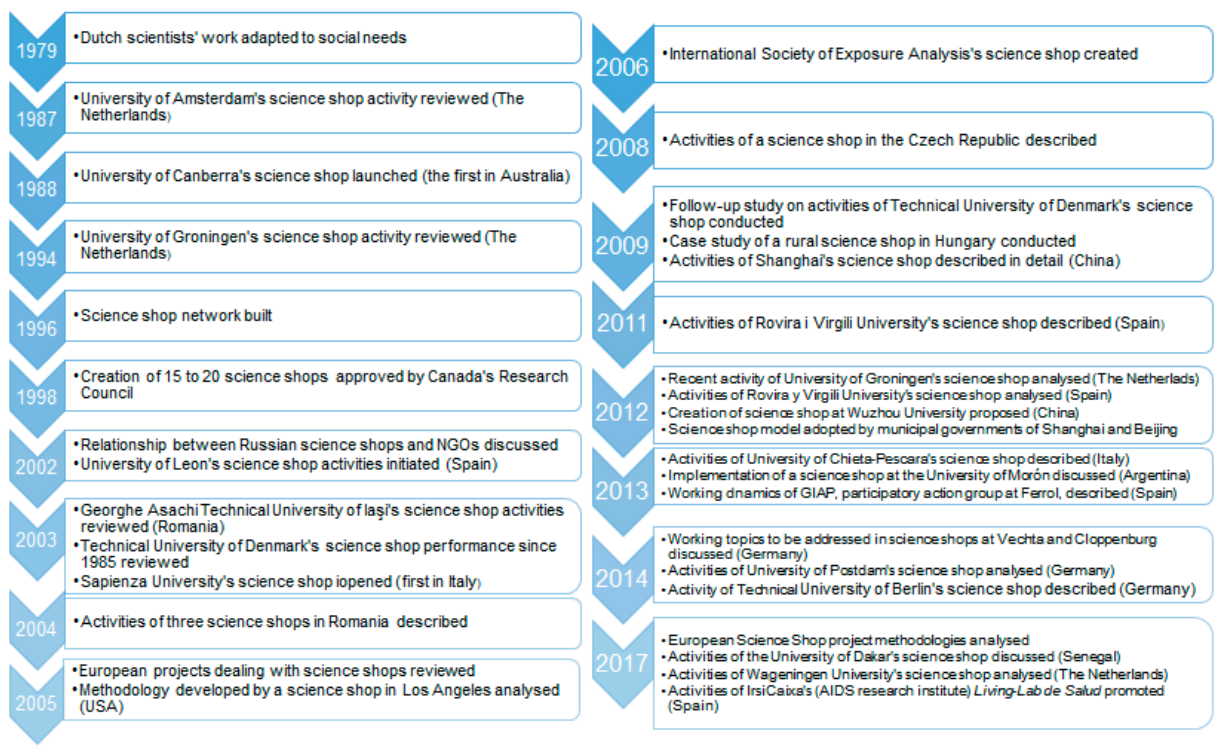

Figure 8. Timeline of science shop activity further to the sources studied. NGO—non-governmental organisation. 


\section{Discussion and Conclusions}

Science shops have had an indisputable social impact on the communities where they are sited, changing the 'doing' and 'building' science paradigm. The significance of their activity cannot be readily traced; however, for while they are often sponsored by universities, they leave a scant imprint on the academic world. Hence, the use in this study of bibliometric techniques to attempt to locate documents dealing with science shops.

The review of international databases revealed that the scientific output on the subject is slim. As a rule, the articles listed in those sources are associated with high quality research of international repute. In as much as the journals indexed publish research of major interest to the international scientific community, the paucity of papers on science shops may denote scant academic acknowledgement of their relevance. That problem has been voiced by a number of scientists who, when asked about the limitations involved in participating in citizen science initiatives, mentioned the lack of acknowledgement, time, and resources devoted by their institutions as one of the primary shortcomings [12]. The rise in the number of papers on citizen science reported by other authors $[9,24]$ was not observed for articles on science shops, where distribution over time is irregular.

Despite its limitations, the analysis showed that papers on science shops are very recent and cluster in the last 10 years, even though the shops themselves have been in place for over 40 years. That change in output dynamics may mirror a trend toward greater acknowledgement of the activity conducted by science shop participants. Another indication of their growing importance is the funding provided by international bodies in recent years, which has favoured the development of sizeable international consortia founded to launch science shop projects. The ongoing furthering of these initiatives and the rise in funding for the respective projects in recent calls for projects attest to the interest they rouse. This trend may be expected to continue, for 'Open Science' is one of the main pillars in the EU's Ninth Framework Programme 'Horizon Europe'.

Further to the information gleaned from the sources used, the subjects best suited to science shop development appear to be related to the environment and health, issues that affect citizens' very directly in their everyday lives. The journals in which articles on the subject were published were classified under categories such as 'Multidisciplinary sciences', 'Education and Educational Research', and 'History and Philosophy of Science' in WoS and 'Social Sciences', 'Arts and Humanities', and 'Environmental Science' in SCOPUS. In contrast, Kullenberg and Kasperowski's [9] bibliometric study on citizen science found a plurality of papers under the WoS heading 'Ecology', followed by 'Environmental Sciences' and 'Geography'. The inference is that papers on citizen science address somewhat different areas than the articles on science shops analysed here.

The data also reveal the significant development of science shops in Europe and their intense activity in universities in countries such as The Netherlands. The explanation is that prevalence may lie in the movement's Dutch origin and the jobs created by that country's Ministry of Science in all its universities to further science shop development [25]. The importance of the activity in this country is also evident in the texts analyzed, where, although case studies from different regions of the world are presented, the case of Holland is always taken as a reference point.

The content addressed varied with the type of document and where it was published. Generally speaking, science shops appear to arise in debates on citizen participation and new ways to create and democratise knowledge. Further to such discussion, their impact spills over into a variety of areas, including the approach to education (by the students involved), research (among the participating scientists), and social issues in the community where the activity is conducted.

Science shops indisputably constitute a prime example of participatory activity and citizen science, given their ability to change the direction taken by research and solve local problems; their priority objective. They bridge the gap between the university and society by favouring two-way, horizontal communication. The challenges to be faced in future include creating further science shops in Europe with the funding for research projects presently underway and analysing and surmounting the limitations identified to date. Sponsoring institutions and especially policy makers may well be urged 
to acknowledge the potential of these initiatives and further participation in their activities as part of the academic endeavour.

Author Contributions: Conceptualization, D.D.F.; Data curation, N.B.-P. and E.M.; Formal analysis, D.D.F. and N.B.-P.; Funding acquisition, E.S.-C.; Methodology, D.D.F.; Visualization, N.B.-P.; Writing—original draft, D.D.F.; Writing-review \& editing, N.B.-P. and E.S.-C.

Funding: This project has received funding from the European Union's Horizon 2020 Research and Innovation Programme under Grant Agreement No. 700583.

Acknowledgments: The methodological developments related to the Open Science study have been carried out within the framework of the project entitled 'Detection of new research and innovation fronts. Analysis of knowledge flows in the scientific domain, industry and society' (ref.: CSO2014-51916-C2-1-R), funded by Spain's Ministry of the Economy and Competitiveness.

Conflicts of Interest: The authors declare no conflicts of interest.

\section{References}

1. STEPS América Latina. Ciencia Abierta, Colaborativa y Alternativa: Un Camino Para Resolver Problemas de Desarrollo. Available online: http:/ / stepsamericalatina.org/ (accessed on 20 June 2018).

2. Silvertown, J. A new dawn for citizen science. Trends Ecol. Evol. 2009, 24, 467-471. [CrossRef] [PubMed]

3. Socientize Consortium. Green Paper on Citizen Science, Citizen Science for Europe: Towards a Better Society of Empowered Citizens and Enhanced Research. The Socientize Consortium of the European Commission 2013. Available online: http:/ / ec.europa.eu/digital-agenda/en/news/green-paper-citizenscience-europe-towards-society-empowered-citizens-and-enhanced-research-0 (accessed on 30 May 2018).

4. Arnstein, S.R. A ladder of citizen participation. J. Am. Inst. Plan. 1969, 35, 216-224. [CrossRef]

5. Shirk, J.L.; Ballard, H.L.; Wilderman, C.C.; Phillips, T.; Wiggins, A.; Jordan, R.; Bonney, R. Public participation in scientific research: A framework for deliberate design. Ecol. Soc. 2012, 17, 29-48. [CrossRef]

6. Serrano Sanz, F.; Holocher-Ertl, T.; Kieslinger, B.; Sanz Garcıa, F.; Silva, C.G. White Paper on Citizen Science for Europe; University of Zaragoza: Zaragoza, Spain, 2014.

7. Irwin, A. Citizen Science: A Study of People, Expertise and Sustainable Development; Routledge: Abingdon, UK, 1995; Volume 216.

8. Riesch, H.; Potter, C. Citizen Science as seen by scientists: Methodological, epistemological and ethical dimensions. Public Underst. Sci. 2014, 23, 107-120. [CrossRef] [PubMed]

9. Kullenberg, C.; Kasperowski, D. What is citizen science?-A scientometric meta-analysis. PLoS ONE 2016, 11, e0147152. [CrossRef] [PubMed]

10. European Commission. Citizen Science Policies in the European Commission: Research Agendas towards Issues of Concern to Citizens. 2018. Available online: http:/ / www.sisnetwork.eu/media/sisnet/Policy_ brief_Citizen_Science_SiSnet.pdf (accessed on 12 March 2018).

11. Kontic, B.; Kontic, D. Baseline Research and Best Practice Report on Participatory and Community-Based Research. 2018. Available online: https://project.scishops.eu/wp-content/ uploads/2018/03/SciShops.eu_D2.1-Baseline-research-and-best-practice-report-on-participatory-andcommunity-based-research.pdf (accessed on 1 September 2017).

12. Sanz-Casado, E.; Mauleón, E.; Alvarado, R.; Bautista-Puig, N. Stakeholders Insights on Participatory Community-Based Research. 2018. Available online: https:/ / project.scishops.eu/wp-content/uploads / 2018/06/SciShops.eu_D3.3-Stakeholders-insights-on-participatory-community-based-research.pdf (accessed on 1 September 2017).

13. Belansky, E.S.; Cutforth, N.; Chavez, R.A.; Waters, E.; Bartlett-Horch, K. An adapted version of intervention mapping (AIM) is a tool for conducting community-based participatory research. Health Promot. Pract. 2011, 12, 440-455. [CrossRef] [PubMed]

14. Conrad, C.C.; Hilchey, K.G. A review of citizen science and community-based environmental monitoring: Issues and opportunities. Environ. Monit. Assess. 2011, 176, 273-291. [CrossRef] [PubMed]

15. Sullivan, B.L.; Wood, C.L.; Iliff, M.J.; Bonney, R.E.; Fink, D.; Kelling, S. eBird: A citizen-based bird observation network in the biological sciences. Biol. Conserv. 2009, 142, 2282-2292. [CrossRef]

16. Raddick, M.J.; Bracey, G.; Gay, P.L.; Lintott, C.J.; Cardamone, C.; Murray, P.; Schawinski, K.; Szalay, A.S.; Vandenberg, J. Galaxy Zoo: Motivations of citizen scientists. arXiv, 2013, arXiv:1303.6886. 
17. Wright, L.A.; King, D.K.; Retrum, J.H.; Helander, K.; Wilkins, S.; Boggs, J.M.; Portz, J.D.; Nearing, K.; Gozansky, W.S. Lessons learned from community-based participatory research: Establishing a partnership to support lesbian, gay, bisexual and transgender ageing in place. Fam. Pract. 2017. [CrossRef] [PubMed]

18. Fischer, C.; Leydesdorff, L.; Schophaus, M. Science shops in Europe: The public as stakeholder. Sci. Public Policy 2004, 31, 199-211. [CrossRef]

19. Leydesdorff, L.; Ward, J. Science shops: A kaleidoscope of science-society collaborations in Europe. Public Underst. Sci. 2005, 14, 353-372. [CrossRef]

20. Bergman, M. Stakeholder Survey Summary Report. 2018. Available online: https://project.scishops.eu/ wp-content/uploads/2018/03/SciShops.eu_D2.3_Stakeholder-survey-summary-report.pdf (accessed on 1 September 2017).

21. Callon, M.; Courtial, J.P.; Penan, H. Cienciometría: La Medición de la Actividad Científica: De la Bibliometría a la Vigilancia Tecnológica; Trea: Gijón, Spain, 1995.

22. Living Knowledge Network. The International Science Shop Network. Available online: http://www. livingknowledge.org/ (accessed on 15 May 2018).

23. Jung, S.; Kleibrink, J. Science Shops Taxonomy. 2018. Available online: https://project.scishops. eu/wp-content/uploads/2018/06/SciShops.eu_D2.5-Existing-Science-Shops-assessment.pdf (accessed on 1 September 2017).

24. Follett, R.; Vladimir, S. An analysis of citizen science based research: Usage and publication patterns. PLoS ONE 2015, 10, e0143687. [CrossRef] [PubMed]

25. Mulder, H.A.J. Science Shops. In Encyclopedia of Science and Technology Communication; Hornig Priest, S., Ed.; SAGE Publications Inc.: Los Angeles, CA, USA, 2010; Volume 2, pp. 733-737.

(C) 2018 by the authors. Licensee MDPI, Basel, Switzerland. This article is an open access article distributed under the terms and conditions of the Creative Commons Attribution (CC BY) license (http:/ / creativecommons.org/licenses/by/4.0/). 